\title{
Impact of Algorithmic Composition on Player Immersion in Computer Games: A Case Study Using Markov Chains
}

\author{
Raul Paiva de Oliveira (Universidade Estadual de Campinas, Campinas, SP, Brazil) \\ raulpo@dca.fee.unicamp.br \\ Tiago Fernandes Tavares (Universidade Estadual de Campinas, Campinas, SP, Brazil) \\ tavares@dca.fee.unicamp.br
}

\begin{abstract}
The feeling of immersion is an important aspect of gaming experiences. It can be greatly impacted by background music. In this work, we investigate the use of algorithmically-generated background music as a mean to generate immersion in gaming experiences. For such, we developed two versions of the same game. One of them uses music written by a composer. The other uses real-time generated melodies based on a Markov chain. We evaluated the immersion level related to each of these versions using user questionnaires and performance measures. The results did show only a small immersion difference between the versions. This indicates that algorithmic music can be a suitable option for game content generation.

Keywords: computer music; immersion; digital games.

Impacto da Composição Algorítmica na Imersão do Jogador em Jogos Digitais: Um Estudo de Caso Utilizando Cadeias de Markov

Resumo: A sensação de imersão é um aspecto importante da experiência de jogo. Ela pode ser afetada em grande medida pela música de fundo. Neste trabalho investigamos o uso de música de fundo produzida através de algoritmos como um meio para produzir imersão em experiências de jogo. Para tal, desenvolvemos duas versões do mesmo jogo. Uma delas utiliza música escrita por um compositor. A outra utiliza melodias produzidas em tempo real com base em cadeias de Markov. Nós avaliamos o nível de imersão associado a cada uma dessas versões utilizando questionários e medições de desempenho. Os resultados mostraram apenas uma pequena diferença em relação ao nível de imersão entre as versões. Isto indica que a música algorítmica pode ser uma opção viável para produção de conteúdo para jogos.
\end{abstract}

Palavras-chave: música computacional; imersão; jogos digitais.

\section{Introduction}

Algorithmic music generation can be a method for fast content creation while preserving great variability. In this paper, we evaluate the impact of algorithmic music on the feeling of immersion in digital games and compare it with that related to human-composed music.

Music in games are typically used as soundtracks recorded previously, which are then associated to specific events, such as the beginning or ending of a level or scene. Such approach can make the music quickly become repetitive, which leads to a decrease in interest in the gaming experience (LIVINGSTONE; BROWN, 2005). In such environments, music generated by algorithms could help breaking the excessive repetition, offering a way to increase in the variety of the musical content. Also, to evaluate how the background music can be related to the gaming experience, it is important to understand the concepts related to immersion.

Immersion in digital games has been defined in many different ways. Brown and Cairns (2004) defined immersion as one's degree of involvement with a game. Ermi and Mäyrä (2005) state that immersion could be defined as a sensation in which one's perception is completely taken over, being fully enveloped by an alternative reality. Brockmyer et al. (2009) also refers to immersion as the potential to induce feelings of being part of the game environment, and that most video game players report experiencing some degree of immersion. 
Immersion is a phenomenon that can be linked to diverse objective measurements (OLIVEIRA; OLIVEIRA; TAVARES, 2016). For this reason, we took into consideration various proposed methods to measure the player's awareness of their own immersion level. The experiment described in this work is based on the one described in Jennet's (2008) and Zhang and Fu's (2015) works.

In this experiment, the participants perform five activities: 1) solving a tangram puzzle $^{1}$, 2) playing the experimental game; 3) answering a questionnaire regarding immersion; 4) playing the game again, and 5) solving the same tangram puzzle as in step 1 . The only difference between the control and test groups was the type of music playing during the game sessions (steps 2 and 4). Immersion levels were evaluated in both groups.

The results showed that the group of users playing the game with traditionally composed music had a slight higher immersion level than the group with procedurally generated music. However, the results didn't show a statistically significant difference in average immersion levels between the control and test group. This can mean that procedurally generated music, albeit a little less effectively, can be a viable alternative for game music production.

The text is organized as follows. Section 2 discusses related work. The experiments performed as well as their results are described in Section 3. A deeper discussion is conducted in Section 4 and, finally, Section 5 concludes the paper.

Related Works

A great number of works related to immersion in digital games and algorithmic generated music has been conducted in the last few years. Jennet et al. (2008) argues that players tend to have more difficult on switching from an immersive activity to a non-immersive one. Thus, after playing the game their performance on solving the tangram puzzle should be worse. To test this hypothesis the participants were asked to solve a tangram puzzle before and after a game session. Also, after the game session the players answered an immersion questionnaire. On the control group, instead of playing a game, the participants performed a computer task that involved clicking on squares appearing on the computer screen. The author's results indicate that, on average, the participants in the test group took more time to complete the tangram after playing the game, hence indicating that they had a higher immersion level.

Zhang and $\mathrm{Fu}$ (2015) proposed an experiment to test if players would experience different levels of immersion playing a game with or without background music. Their experiment was based on Jennet's, comprising solving puzzles, playing the game for a pre-defined length and answering a questionnaire. The results showed that players in the group with background music reported experiencing a higher feeling of immersion.

Video games can be experiences with a very dynamical audiovisual environment. Thus, techniques for generating musical content procedurally could be exploited to deliver a more diversified material, or even one that bears a more meaningful relationship with the player's experience.

The GenJam model proposed by Biles (1994) was inspired on the typical behavior of an improviser musician in the Jazz style. It uses genetic algorithms to generate phrases and melodies in real time, using a sequence of symbols representing musical notes in the form of discrete events. Combined, they form hierarchically related melody pieces, that is, measures, formed by musical notes, and phrases, formed by measures. In this model, the fitness of each individual (measure of phrase) is estimated by the behavior of the musician that interacts with the system.

Also, statistical models generated interesting results, as it is the case of the OMax 
project (ASSAYAG; BLOCH; CHEMILLIER, 2006). It uses a multilevel Markov chain to simulate improvisation. Thus, after receiving MIDI events from a musician, it generates musical pieces with similar characteristics.

Livingstone and Brown (2005) propose the use of adaptive music in digital games, altering musical elements in real time to communicate the desired emotions. To achieve this, their system employs a set of rules relating emotions to musical elements. According to the authors, it successfully communicates emotions such as 'Happy', 'Sad' and 'Dreamy'.

Besides that, models proposed for computer assisted composition, such as McVicar, Fukuyama and Goto (2014), have showed promising results. This algorithm proposed by the authors analyzes rhythmic and melodic characteristics from transcriptions of music played by guitarists from different styles. Then, these characteristics are employed to generate new musical pieces, replicating the playing style of a given guitarist. Such work provides valuable insight towards the creation of procedural content in an interactive gaming environment.

\section{Experiment}

The game used in this work, as shown in Figure 1-a, is an infinite runner - that is, a game in which the character runs in an infinite track and must avoid obstacles and collect bonuses that helps their survival. In our game, the character loses one life point for each collision with a vehicle, and in turn recovers one life point by collecting a heart bonus (Figure 1-b). An hourglass bonus slows down vehicles to make it easier to avoid the obstacles (Figure 1-C).

(a)

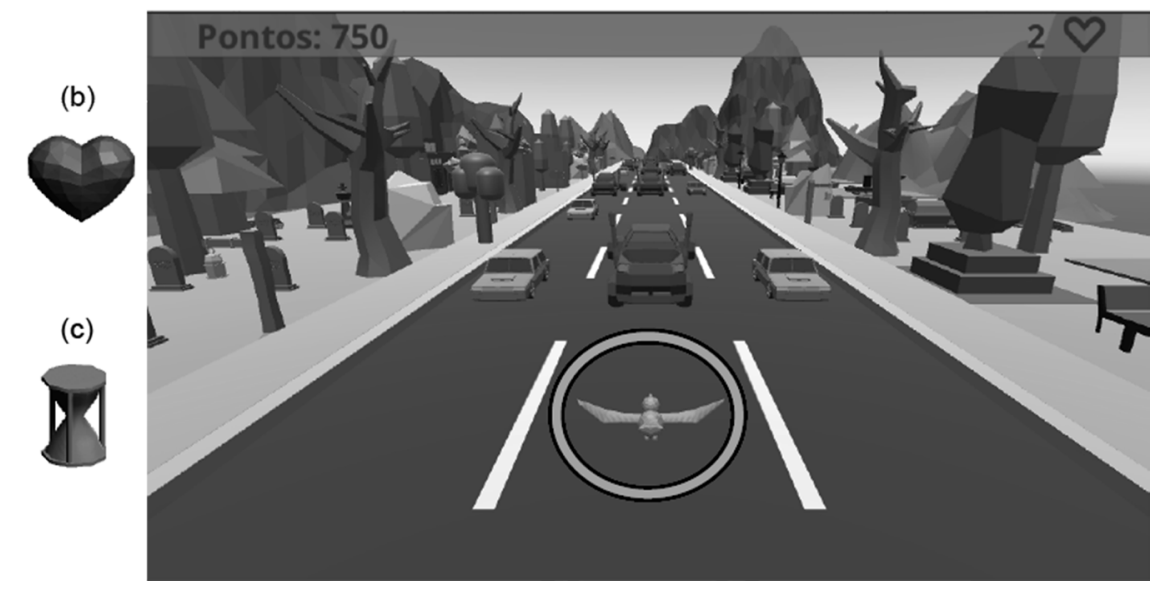

Figure 1: Experimental Game Screenshot. The character is inside the highlighted circle (a). The character has to avoid the vehicles and collect the bonus hearts (b) and hourglasses (c).

Figure 2 shows how the two different background music types are employed in the game. For the Control Group, the composed music in MIDI format was simply played by the game engine in an infinite loop. To generate the music for the Test Group, the same MIDI file used in the control group was split into two musical note lists representing its two melodies, and each list was further split into a list of note frequencies and a list of note durations. After that, we generated four Markov Chain models from the original music, one for each of the frequency or note lists. After this, each pair of models was used to generate a frequency and duration, joined into a musical note. The two new notes would then be played, and the note generation process would be repeated as needed. 


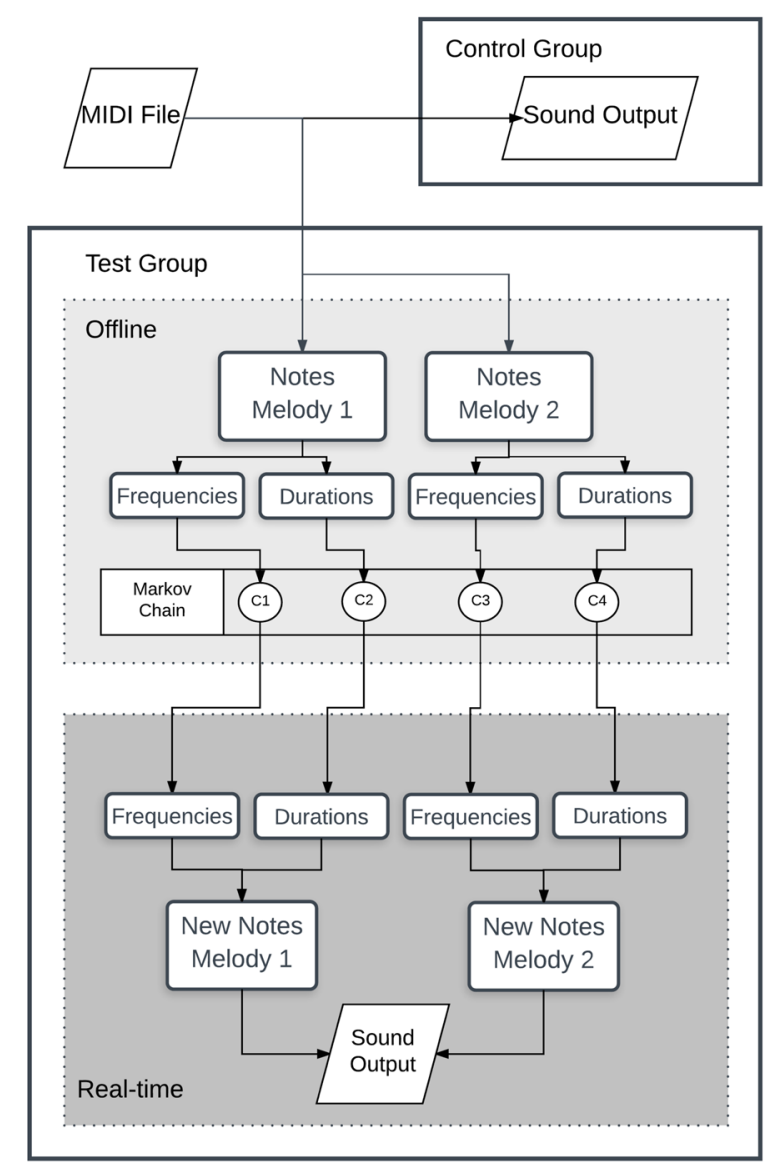

Figure 2: Process used to generate background music for the control group (MIDI loop) and the test group (procedurally generated music).

Figure 3 shows an example of a Markov Chain modeling these events. The composed music was a two-instrument arrangement of the 'Green Hill Zone' stage music, from the game 'Sonic the Hedgehog' (NAKAMURA, 1991).

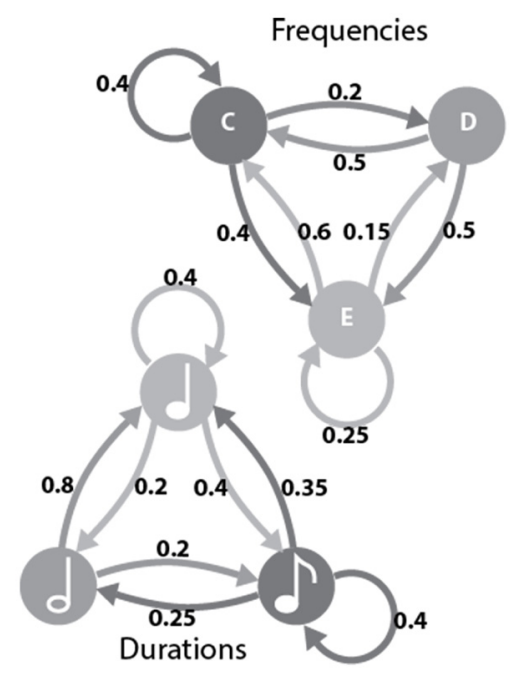

Figure 3: Example Markov Chain that can be used to automatically generate content.

Figure 4-a shows an excerpt from the original music used for the control group. Figure 4-b to Figure 4-e show four example segments generated with the Markov Chain for the control group. 


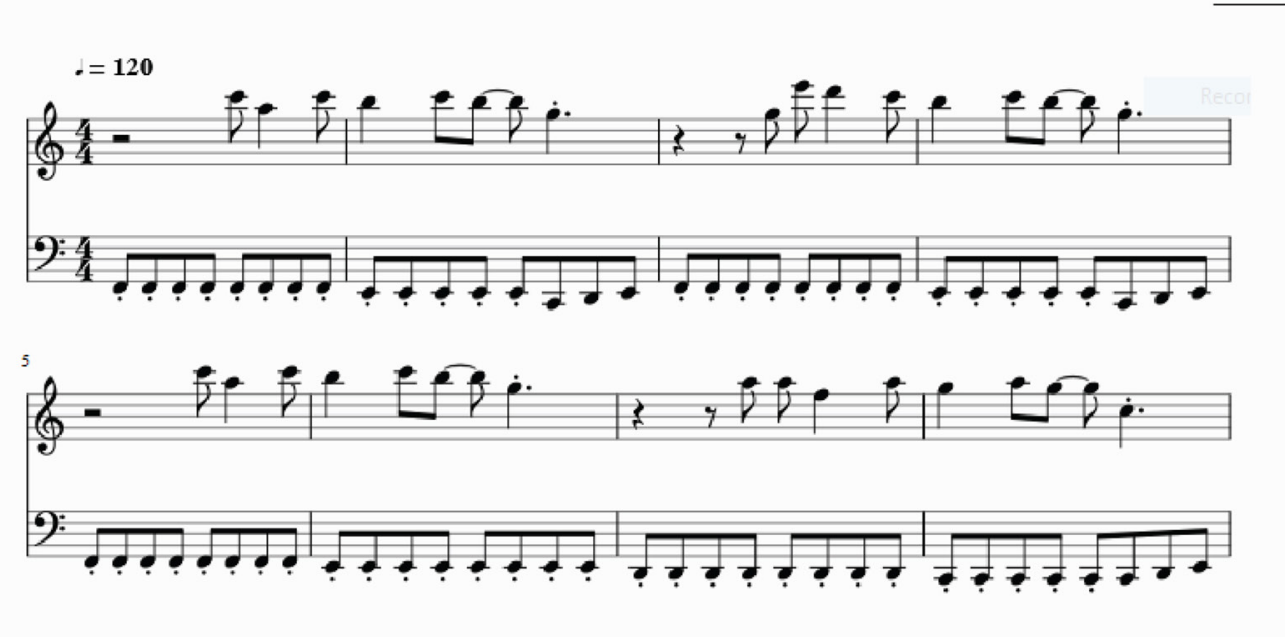

(a)

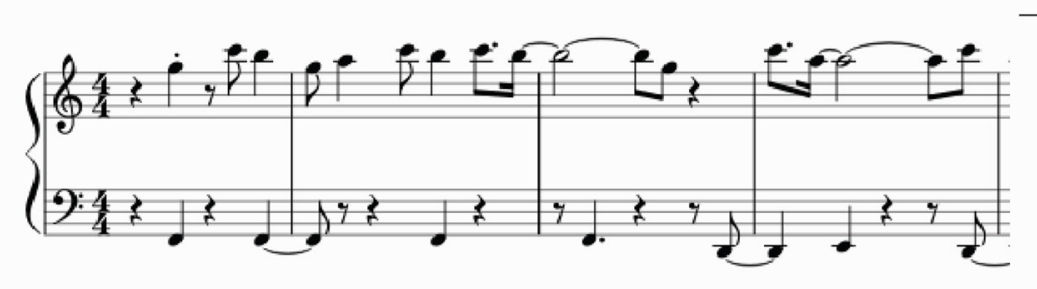

(b)

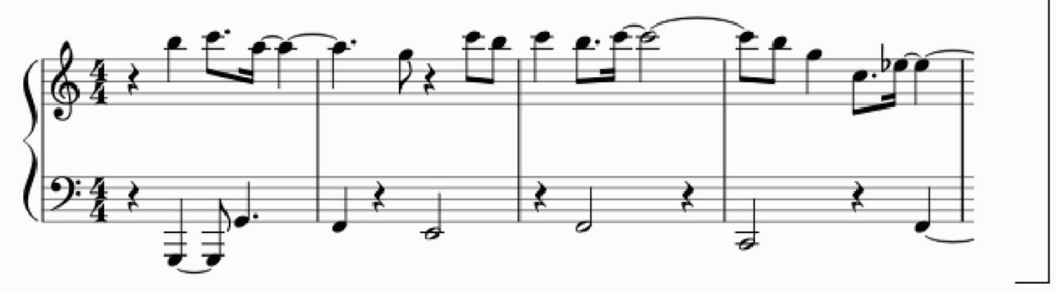

(c)

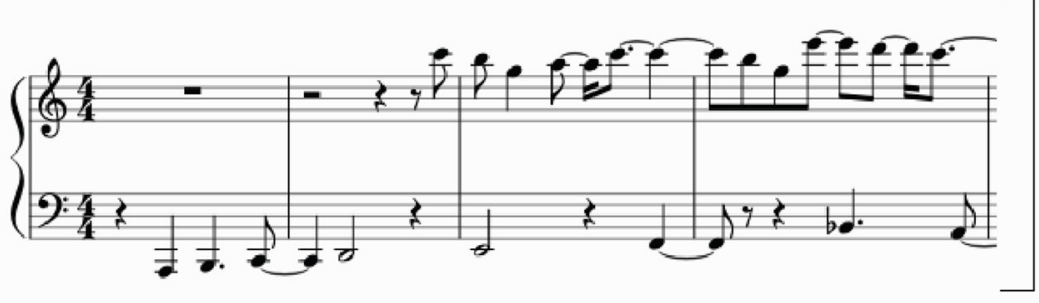

(d)

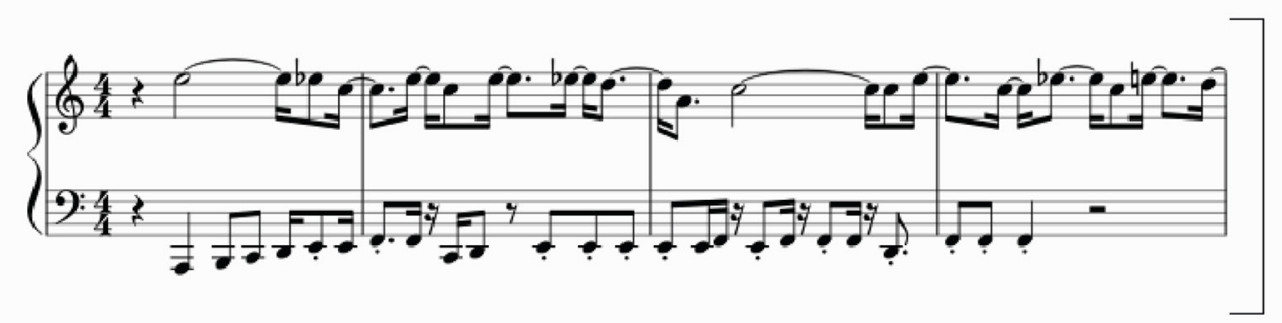

(e)

Figure 4: Control melody excerpt (a) and four example melodies generated for the experiment group (b-e). The corresponding MIDI files are available alongside this text as supplementary material. ${ }^{2}$

\section{Participants}

The sequence of steps proposed in this experiment was based on previous work by Jennet et al. (2008) and Zhang and Fu (2015). We invited 38 participants students from FATEC (Faculdade de Tecnologia do Estado de São Paulo) and divided them randomly in two groups of 19 members. This research was approved by the Ethics Committee at UNICAMP (Universidade Estadual de Campinas). All the participants were students from the Game Development course, with diverse age, gender and musical training. 


\section{Structure and Procedure}

During the experiment, each participant was instructed to run the program to start the following procedures: 1) solving a tangram puzzle, 2) playing the game; 3) answering a questionnaire regarding immersion; 4) playing the game again, and 5) solving the same tangram puzzle as in step 1 . The time limit for solving the tangram puzzle was defined as five minutes, due to time constrains related to the experiment location.

After 10 minutes of playing the game, the session was interrupted for answering the questionnaire. It contains 31 questions relating to immersion, with answers ranging from 1 (none) to 5 (very much).

After answering the whole questionnaire, the participant returns to the game session for another 10 minutes. Finally, after this session the player must solve the same tangram puzzle as in the first step. Figure 5 summarizes the experimental steps.

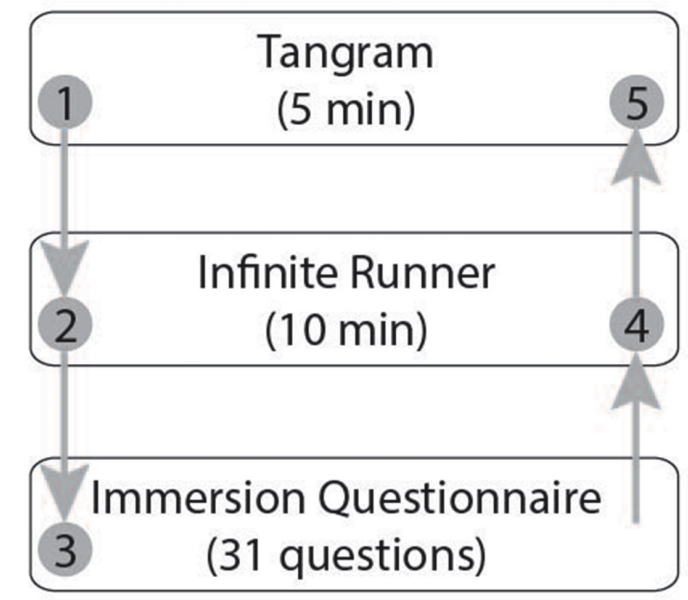

Figure 5: Flowchart describing the experiment. It begins with a tangram puzzle, proceeds to game playing, then to the immersion questionnaire. After that, game playing is repeated and the tangram puzzle is solved again.

Performance data was also collected throughout the whole player's participation. This data comprises best and worst score in both game sessions, the time interval required to solve the first and second puzzles, and the performance improvement in solving the puzzle.

\section{Results}

Based on answers from the questionnaire and the players' performance in the game and puzzle, we analyzed the interaction between the player's immersion levels with the different types of music to which the participants were exposed to during game sessions. Answers were grouped as in Jennet et al. (2008) with six groups: basic attention, temporal dissociation, transport, challenge, emotional involvement and enjoyment.

The first question group is: “To what extent did the game hold your attention?” (Q1); "To what extent did you feel you were focused on the game?" (Q2); "How much effort did you put into playing the game?” (Q3); “Did you feel you were trying your best?” (Q4) ${ }^{3}$. Figure 6 represents the mean score for each answer, divided by test and control group. Among the questions in the first group, the question Q4 was the only one where the test group's mean was bigger than that of the control group. The control group then, in general, had their attention focused on the game session. 


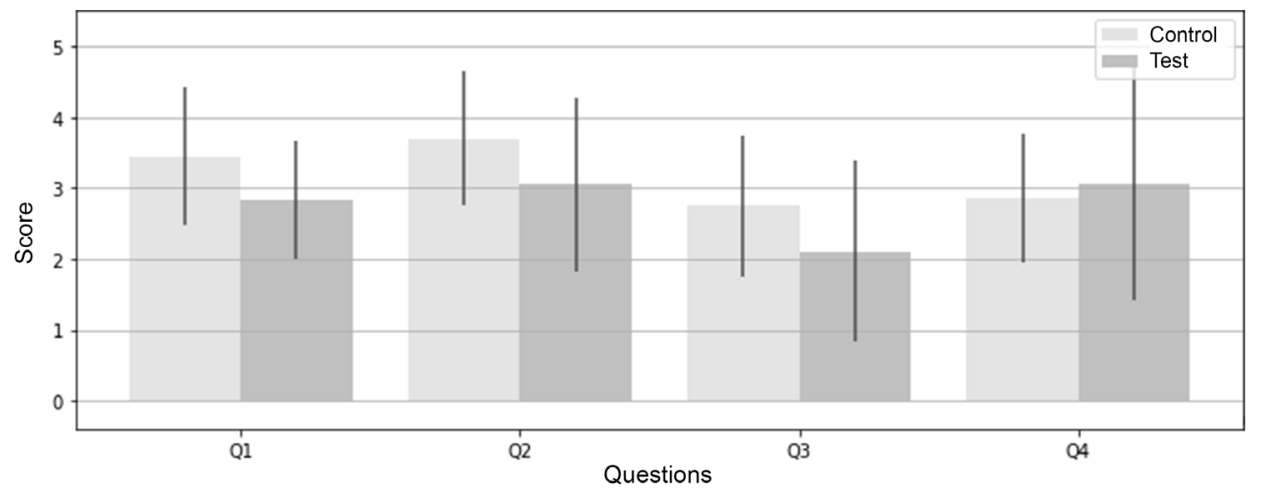

Figure 6: Mean and standard deviation of questions on Basic Attention group from the questionnaire.

The second question group encompasses six questions: "To what extent did you lose track of time?" (Q5); "To what extent did you feel consciously aware of being in the real world whilst playing?” (Q6); “To what extent did you forget about your everyday concerns?” (Q7); “To what extend were you aware of yourself in your surroundings?” (Q8); “To that extent did you notice events taking place around you?" (Q9); "Did you feel the urge at any point to stop playing and see what was happening around you?” (Q10) ${ }^{4}$. It is important to highlight that in this group only the questions Q5 and Q7 contribute positively to the total immersion score, while the questions Q6, Q8 and Q10 contribute negatively to the total immersion score. In the temporal dissociation group all means which contribute positively to the immersion score were higher in the control group, as Figure 7 shows. The answers to questions Q5 and Q10 were the ones with the larger difference in means. Thus, the control group answered more favorably to the feeling of losing track of the passage of time, and less favorably to the question about feeling compelled to stop playing to look around.

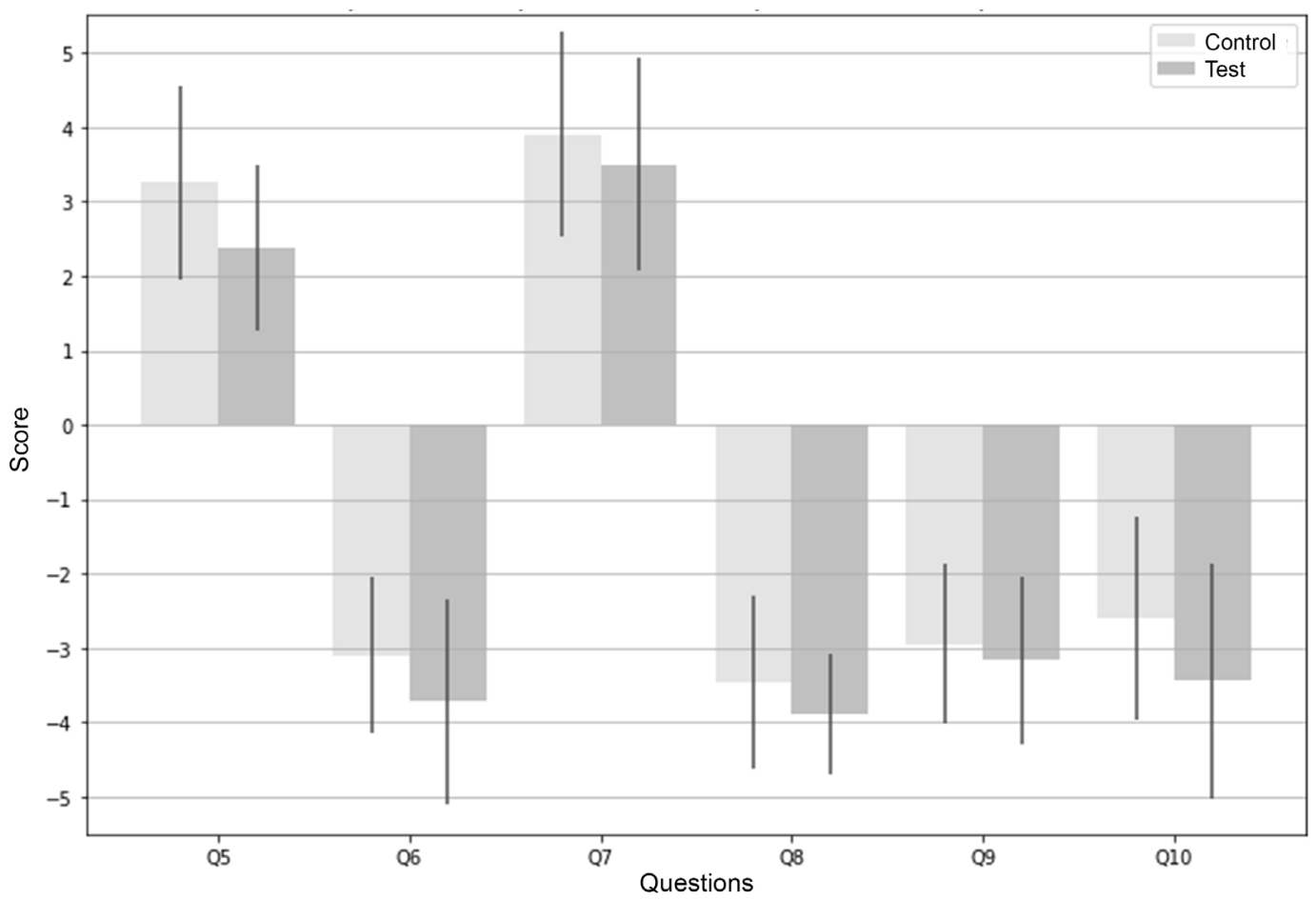

Figure 7: Mean and standard deviation of questions on Temporal Dissociation group from the questionnaire.

The third group refers to the six questions related to the concept of transport: "To what extent did you feel that you were interacting with the game environment?” (Q11); “To what extent did you feel as though you were separated from your real-world environment?" 
(Q12); “To what extent did you feel that the game was something you were experiencing, rather than something you were just doing?” (Q13); “To what extent was your sense of being in the game environment stronger than your sense of being in the real world?" (Q14); "At any point did you find yourself become so involved that you were unaware you were even using controls?" (Q15); “To what extent did you feel as though you were moving through the game according to your own will?" (Q16) ${ }^{5}$. Figure 8 shows that the test group obtained a higher mean only in question Q13, when compared to the control group.

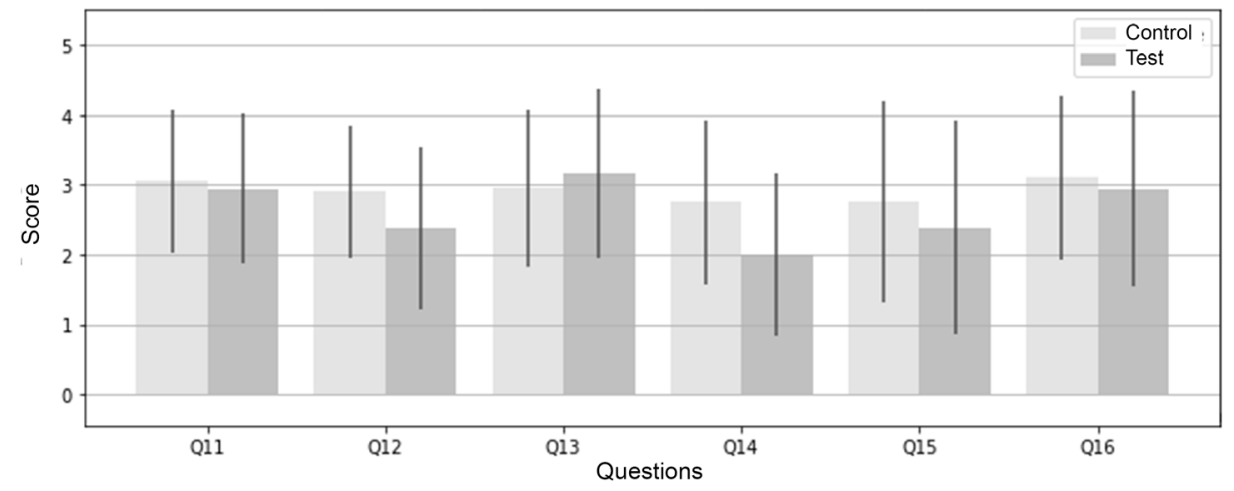

Figure 8: Mean and standard deviation of questions on Transport group from the questionnaire.

The fourth group regards six questions about challenge: "To what extent did you find the game challenging?" (Q17); "Were there any times during the game in which you just wanted to give up?” (Q18); “To what extent did you feel motivated while playing?” (Q19); "To what extent did you find the game easy?" (Q20); "To what extent did you feel like you were making progress towards the end of the game?" (Q21); "How well do you think you performed in the game?” (Q22) ${ }^{6}$. As shown in Figure 9, the questions Q18 and Q20 contribute negatively to the total immersion score. The questions Q18 and Q22 had a more favorable result in the test group, and the remaining questions had more favorable answers in the control group. The answers in the test group indicate a higher cognitive effort among members of that group, as also felt that they have had a better performance during the game session.

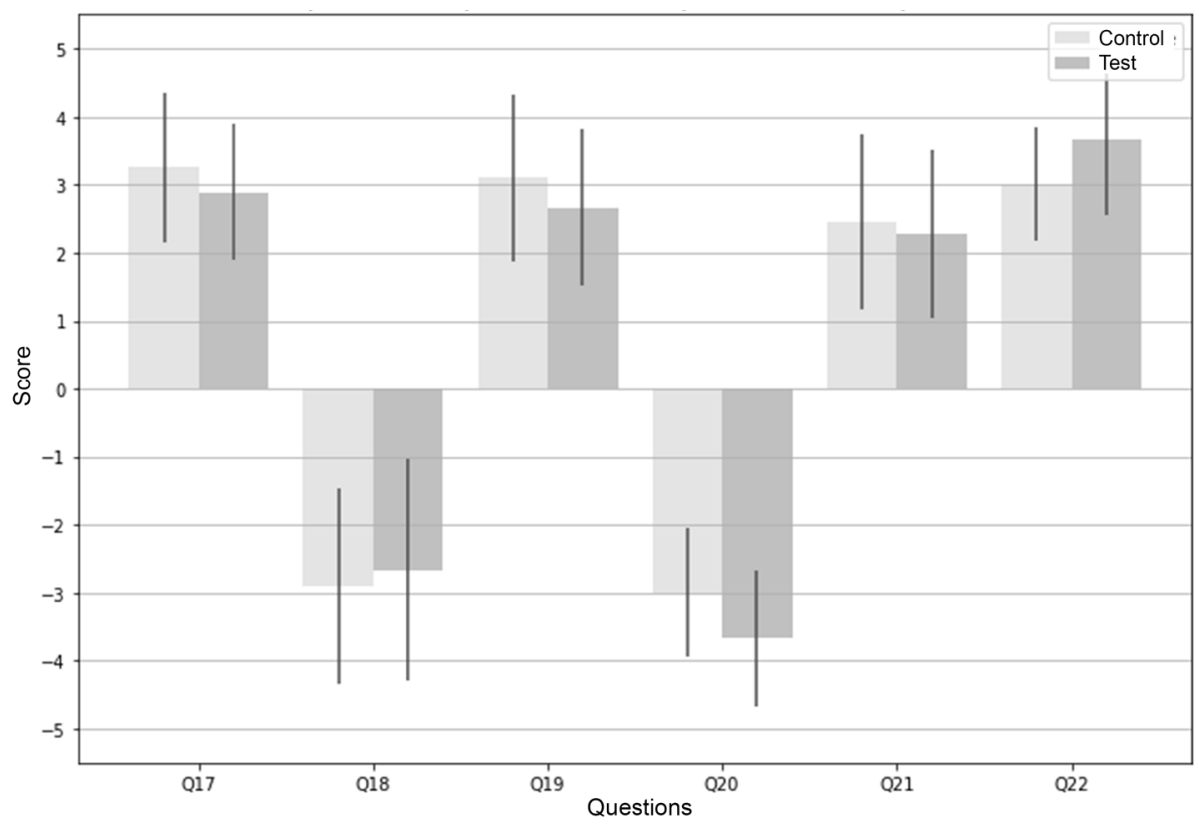

Figure 9: Mean and standard deviation of questions on Challenge group from the questionnaire. 
The fifth group contains the five questions related to the emotional involvement of the participants, with the following questions: "To that extent did you feel emotionally attached to the game?” (Q23); “To what extent were you interested in seeing how the game's events would progress?” (Q24); “How much did you want to 'win' the game?” (Q25); “Were you in suspense about whether or not you would win or lose the game?" (Q26); "At any point did you find yourself become so involved that you wanted to speak to the game directly?" $(Q 27)^{7}$. Figure 10 shows that all means in the test group were smaller than the control group ones, indicating that the participants felt a greater emotional attachment to composed music than to the algorithmically composed music.

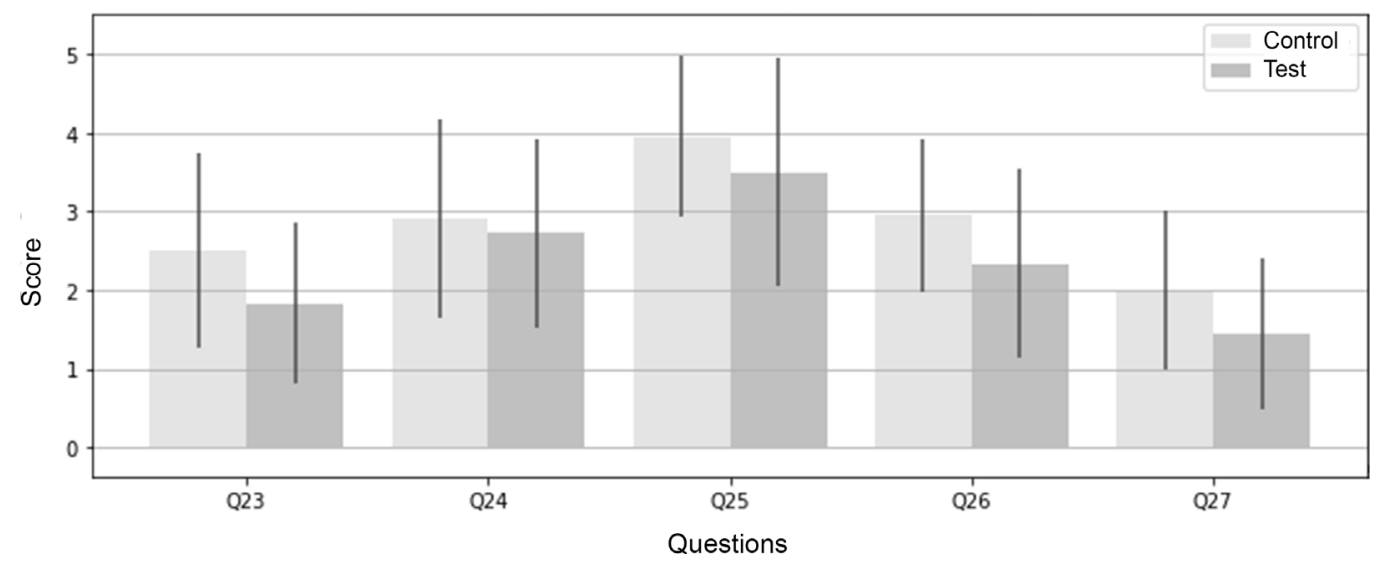

Figure 10: Mean and standard deviation of questions on Emotional Involvement group from the questionnaire.

Finally, the sixth group encompass the following questions regarding enjoyment: "To what extent did you enjoy the graphics and the imagery?" (Q28); "How much would you say you enjoyed playing the game?” (Q29); “When interrupted, were you disappointed that the game was over?” (Q30); “Would you like to play the game again?” (Q31) ${ }^{8}$. Figure 11 shows that in these questions the control group also had a bigger mean than the test group, despite the means for questions Q28 and Q31 being close in both groups. Such results show that the music generated algorithmically did not affect to a great extent the participant's perception of the visual elements of the game. Also, there wasn't a great difference regarding the desire to participate in the game again in the future between both control and test groups.

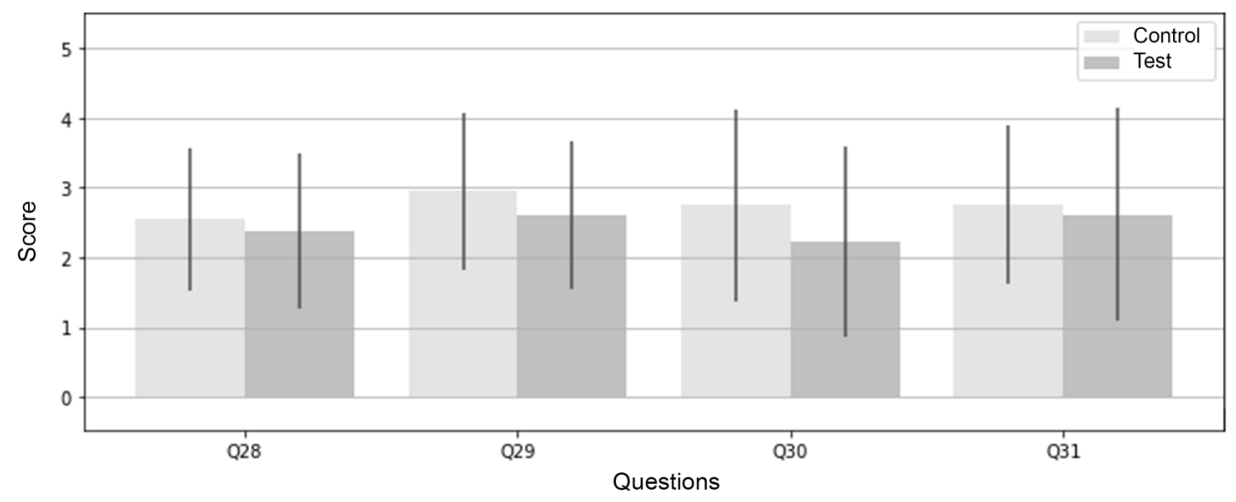

Figure 11: Mean and standard deviation of questions on Enjoyment group from the questionnaire.

Each one of the questions above contributed to the sum of the immersion score. The Figure 15 presents the mean and standard deviation of each of the evaluated parameters, in the control and test groups. These are: 1) total score in the immersion questionnaire; 2) time spent to solve the first puzzle; 3 ) time took to solve the second puzzle; 4) performance 
gain solving the second puzzle; 5) and 6) maximum and minimum score during the first runner game session; 7) and 8) maximum and minimum score during the second runner game session.

As can be observed in the Figure 12, the control group participants (with composed music) presented a greater mean score in their answers to the immersion questionnaire, of approximately 50\%, when compared to the test group (with algorithmic music), with a mean of approximately $40 \%$. However, the group with music generated with algorithms obtained a smaller performance gain when trying to solve the puzzle for the second time.

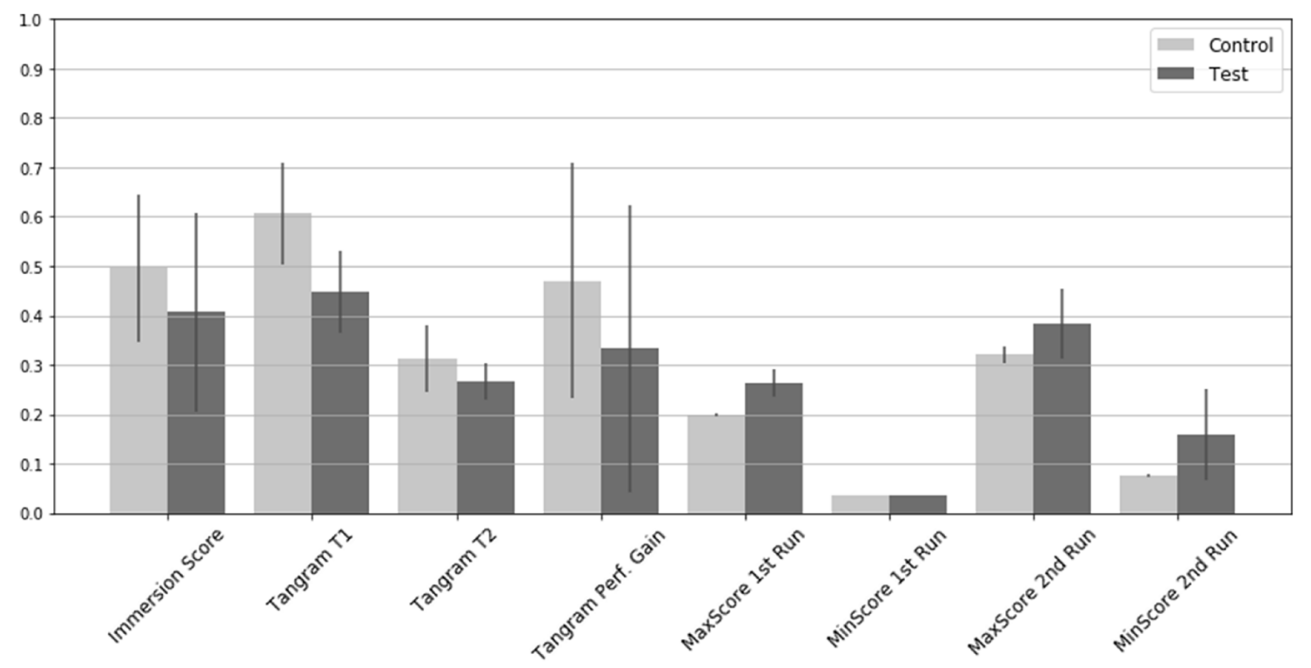

Figure 12: Mean and standard deviation by parameter and by test or control group.

\section{Discussion}

The immersion questionnaire, proposed by Jennett et al. (2008) and also used in our work, evaluates a sum of factors attributed to the one's perception of their own feeling of immersion. Despite the small difference in the total scores between the control and test groups, there was a difference in the means of each question. While the control group had a bigger mean score in the majority of the answers, the test group answered more favorably to some questions in the Basic Attention, Transport and Challenge groups.

The results obtained contradict partially the findings in Jennett et al. (2008) and Zhang and $\mathrm{Fu}$ (2015), in which a greater score in the immersion questionnaire was related to a greater performance gain solving the puzzle. The results suggest that the presence of this type of algorithmically generated music would be related to a bigger cognitive effort employed to play, but not necessarily related to the totality of the broader phenomena described as immersion. This extra effort while playing the intermediate step would then make it more difficult to fixate or transfer knowledge acquired in the first attempt at solving the tangram puzzle. This idea is corroborated by the more favorable answers by the test group to questions in the immersion questionnaire that relate to challenging aspects, such as "Have you felt you were giving your best?". The participants in the test group answered more favorably to the question Q22, related to the positive perception about their performance in the game session. Beyond that, the participants on the test group in fact had a bigger mean score in both sessions of the infinite runner game, and also were able to solve the puzzle faster. Also, the results suggest that this sensation is not exactly the same sensation accentuated by the composed music. The later would be more closely related to a stronger aesthetic component. This due to the control group's answers being more favorable to ques- 
tions as "How much you would say you enjoyed playing the game?" and "To which degree you felt emotionally attached to the game?"

Despite that the music produced by the algorithm didn't provide an increase in the feeling of immersion when compared to the traditional music, it is important to discuss this result in contrast to the findings in the literature. In Zhang and Fu's (2015) research, the difference between the immersion level among groups was larger than the difference among the groups in this experiment. The music composed by traditional means used in this work has structures and patterns that are repeated in a predictable sequence, contrary to the music generated through the Markov chains for the test group. The examples available in Figure 4 show that in the group with algorithmic music, both melody and rhythm behave in a random manner, not having familiar elements such as phrases that repeat frequently.

It can be argued that what allows the music produced by algorithms to influence the player's feeling of immersion is its ability or inability to generate patterns similar to the structures and repetitions present in music composed by traditional means. A first order Markov chain, as the one used in this experiment, doesn't have the capability to model musical structures that depend on a long sequence of events.

However, it is also not possible to affirm that complex musical structures are essential for the listener to experience an average feeling of immersion. The mere presence of sound resources that could imitate, even poorly, the typical structures of a traditionally composed soundtrack may be sufficient to attain a higher feeling of immersion than an environment without a soundtrack.

The quality of the sounds for the synthesis process could have been a factor responsible for the immersion levels being low in both groups. The choice for the sonority of the instruments was based on the typical sound quality of the early 1990s games, the period when the game Sonic The Hedgehog was released. It was expected that, with these sounds with a cruder quality when compared to current games, it was possible to provide an experience compatible with the stylized visual elements employed in the development of the test game.

Factors without a direct relationship with the background music may also have affected the experiment participants, in both groups. Since all participants were in the same room, the presence of the other participants, as well as the noise during the experiment procedure, may have distracted or lowered the concentration of the players towards the game session. The experiment's total duration may also have had a negative effect to the feeling of immersion due to fatigue. Some participants stated that the game of the infinite runner specifically, with a fixed length of 10 minutes, and with 20 minutes in total due to the two steps, was excessively long. Beyond that, taking into account the two attempts to solve the puzzle with a maximum length of 5 minutes and also the time took to answer the questionnaire, the total duration of the experiment ranged between 25 to 40 minutes.

Other factor that may have had an effect on the immersion level of the control group is the fact that the composed music used is broadly known. The possible recognition of the music by the players, as well as a feeling of familiarity or emotional connection with the game to which the music belongs, may have influenced the level of immersion of the participants on the control group to some degree.

\section{Conclusion}

We conducted an experiment to evaluate the impact of algorithmically generated background music on player immersion in digital games. Half of the subjects played a ga- 
me with composed music and the other half played a similar game, with computer-generated music. Results show that algorithmic music reinforces cognitive aspects of immersion, whereas composed music is linked to higher aesthetic and emotional aspects of immersion. This suggests that algorithmically composed music can be a viable alternative to looping music for game content generation.

\section{Note}

1 Chinese puzzle consisting of a large square cut into seven pieces, namely five triangles, one square and one parallelogram. The puzzle's objective is to form a given shape, usually represented by an outline, using all seven pieces without any overlap.

2 MIDI files available at: <https://emac.ufg.br/p/23947-oliveira>.

3 The questions from the first group were delivered in Portuguese as follows: "Em que medida o jogo prendeu sua atenção?" (Q1); "Em que medida você se sentiu focado no jogo?” (Q2); "Quanto esforço você realizou para jogar?” (Q3); "Você sentiu que estava dando seu máximo?" (Q4).

4 The questions from the second group were delivered in Portuguese as follows: "Em que medida você perdeu a noção do tempo?” (Q5); “Em que medida você se sentiu consciente de estar no mundo real enquanto jogava?” (Q6); "Em que medida você se esqueceu de suas preocupações quotidianas?" (Q7); "Em que medida você estava consciente de si próprio em seu entorno?" (Q8); "Em que medida você percebeu eventos acontecendo em volta de você?” (Q9); "Você se sentiu compelido em algum momento a parar de jogar para ver o que estava acontecendo em torno de você?" (Q10).

5 The questions from the third group were delivered in Portuguese as follows: "Em quem medida você sentiu que estava interagindo com o ambiente do jogo?" (Q11); "Em que medida você sentiu como se você estivesse separado do ambiente do seu mundo real?" (Q12); "Em que medida você sentiu que o jogo foi uma experiência para você, ao invés de apenas algo que você estava simplesmente fazendo?" (Q13); "Em que medida a sua sensação de estar no jogo foi mais forte que a sensação de estar no mundo real?" (Q14); "Em algum momento você percebeu estar tão envolvido que perdeu mesmo a noção de estar usando controles?" (Q15); "Em que medida você sentiu como se você estivesse se movendo pelo jogo de acordo com sua vontade?" (Q16)

6 The questions from the fourth group were delivered in Portuguese as follows: "Em que medida você achou o jogo desafiador?" (Q17); "Houve momentos durante o jogo em que você simplesmente quis desistir?" (Q18); "Em que medida você se sentiu motivado enquanto jogava?" (Q19); “Em que medida você achou o jogo fácil?" (Q20); “Em que medida você sentiu que estava avançando" (Q21); “Como você avalia seu desempenho no jogo?” (Q22).

7 The questions from the fifth group were delivered in Portuguese as follows: "Em que medida você se sentiu emocionalmente ligado ao jogo?” (Q23); "Em que medida você estava interessado em ver como os eventos do jogo avançariam?” (Q24); “Quanta vontade você tinha de vencer o jogo?” (Q25); "Você sentiu-se em suspenso sobre se você ganharia ou perderia o jogo?" (Q26); "Em algum momento você se sentiu tão envolvido que você queria falar diretamente com o jogo?" (Q27).

8 The questions from the sixth group were delivered in Portuguese as follows: "Em que medida você gostou dos gráficos e imagens?” (Q28); “Quanto você diria ter gostado de jogar?” (Q29); “Quando interrompido, você se sentiu desapontado porque o jogo tinha acabado?” (Q30); "Você gostaria de jogar novamente?” (Q31).

\section{References}

ASSAYAG, Gérard; BLOCH, Georges; CHEMILLIER, Marc. OMax-Ofon. In: Sound and Music Computing (SMC) 2006, Marseille. p. 1-8, 2006.

BILES, John A. GenJam: A genetic algorithm for generating jazz solos. In: Proceedings of the International Computer Music Conference, p. 131-137, 1994.

BROCKMYER, Jeanne H.; FOX, Christine M.; CURTISS, Kathleen A.; MCBROOM, Evan; BURKHART, Kimberly M.; PIDRUZNY, Jacquelyn. The development of the game engagement questionnaire: A measure of engagement in video game-playing. Journal of Experimental Social Psychology, p. 624-634, 2009.

BROWN, Emily; CAIRNS, Paul. A grounded Investigation of Game Immersion. CHI 2004 Conference on Human Factors in Computing Systems, p. 1297-1300, 2004. 
ERMI, Laura; MÄYRÄ, Frans. Fundamental Components of the Gameplay Experience: Analysing immersion. In: CASTELL, Suzanne de (Ed.). Worlds in Play: International Perspectives on Digital Games Research. United States of America: Peter Lang Pub, n. 2, p. 37-53, 2005.

JENNETT, Charlene; COX, Anna L.; CAIRNS, Paul; DHOPAREE, Samira; EPPS, Andrew, TIJS, Tim; WALTON, Alison. Measuring and defining the experience of immersion in games. International Journal of Human-Computer Studies, p. 641-661, 2008.

LIVINGSTONE, Steven R.; BROWN, Andrew R. Dynamic response: real-time adaptation for music emotion. In Proceedings of the second Australasian conference on Interactive entertainment, p. 105-111, 2005.

MCVICAR, Matt; FUKAYAMA, Satoru; GOTO, Masataka. AutoRhythmGuitar: Computer-aided composition for rhythm guitar in the tab space. In: International Computer Music Conference, p. 14-20, 2014.

NAKAMURA, Masato. Green Hill Zone. Sonic the Hedgehog. Producer: Sega Genesis. 1991.

OLIVEIRA, Raul P. de; OLIVEIRA, DENISE. C. P. de; TAVARES, Tiago F. Measurement methods for phenomena associated with immersion, engagement, flow, and presence in digital games. In: Proceedings of the SBGames Conference, 15, São Paulo, Brazil, p. 127-135, 2016.

ZHANG, Jiulin; FU, Xiaoqing. The Influence of Background Music of Video Games on Immersion. Journal of Psychology \& Psychotherapy, v. 5, n. 4, p. 1, 2015.

Raul Paiva de Oliveira - Possui graduação em Jogos Digitais pela Faculdade de Tecnologia de Americana(2012) e mestrado em Engenharia Elétrica pela Universidade Estadual de Campinas(2017). Tem experiência na área de Ciência da Computação, com ênfase em Sistemas de Computação. Atuando principalmente nos seguintes temas: computação musical, aprendizado de máquina.

Tiafo Fernandes Tavares - Professor na Faculdade de Engenharia Elétrica e de Computação da Unicamp. Possui graduação em Engenharia de Computação pela Universidade Estadual de Campinas (2007). Defendeu dissertação de mestrado, intitulada Transcrição Automática do Baixo em Músicas Populares com Processamento de Sinais Baseado em Predição Linear; em março/2010. Fez doutorado em Engenharia Elétrica na Universidade Estadual de Campinas, tese defendida em outubro/2013. Conduziu pesquisa de pós-doutorado em musicologia assistida por computador no Núcleo Interdisciplinar de Comunicação Sonora (NICS) - Unicamp. 